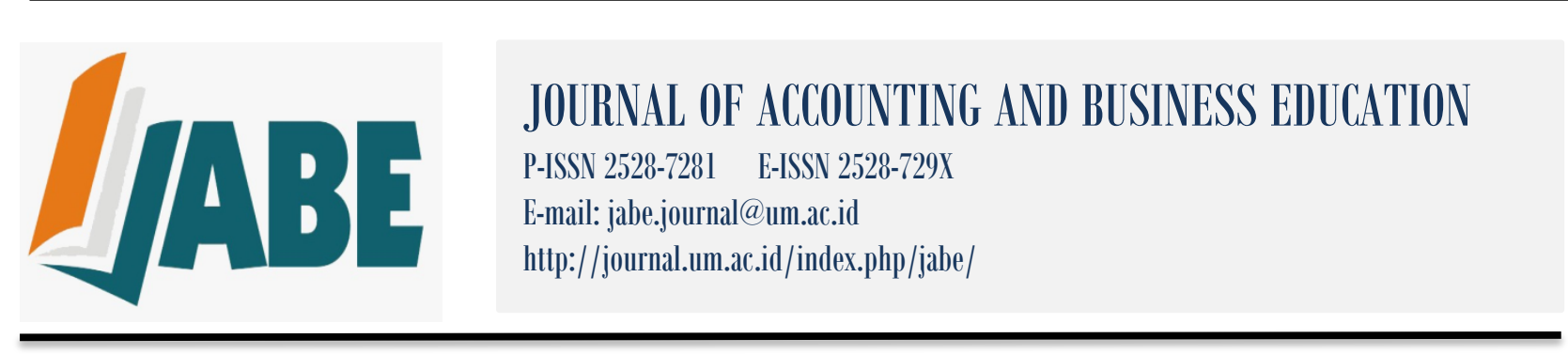

\title{
The Development of M-Learning Based on Integration-Interconnection of The Accounting Cycle of Trading Company
}

\author{
Putri Adisti Kamadita \\ Nujmatul Laily \\ Universitas Negeri Malang \\ adistykamadita@gmail.com
}

\begin{abstract}
This study aims to produce a mobile learning application based on the topic of integrationinterconnection of the trading company. The application is useful as an alternative to independent learning that can support the learning of accounting students. This research was a development research which refers to the development procedure of Borg and Gall which was modified into seven steps. Data in this study were collected using a questionnaire. The results of the study showed that the percentage of eligibility of the material expert validator was $73 \%$, the media expert validator was $98 \%$, the integrationinterconnection expert validator was $75 \%$, and the respondent was $79 \%$. The average percentage of eligibility is $81 \%$. This number means that the application is very feasible to use. Some suggestions that can be given for further development of the application are by making indicators of specific expert validation measurements with supporting references; provide competency updates to the application and add new practice questions; the presentation of the verses of the Qur'an and Hadith can be added so that the students' knowledge of the relationship between the Qur'an, Hadith, and accounting becomes wider; as well as product testing, so that the level of effectiveness of learning media products can be known.
\end{abstract}

Keywords: m-learning, integration-interconnection, the accounting of the trading company

\section{INTRODUCTION}

The concept of learning has a broad understanding from various perspectives within the context of education. However, in the opinion of Brooks and Brooks (in Hanifiah and Cucu, 2012: 62), learning theory is brought close to the constructivist paradigm, which means that an approach to teaching and learning leads to the discovery of a concept that is generated from the views and images of students. The constructivist approach to learning is done through a process of personal exploration, reflection discussion, and writing. This is consistent with the practice that has been occurring at a higher education institution where students are asked to be more active in seeking and building concepts based on what they learn independently. The role of the 
lecturer in constructivism learning is as a facilitator or moderator. As a facilitator, The lecturer plays an important role in making it easy for students during the learning process hence the learning objectives can be accomplished. In other words, students are more directed to learn independently.

One of the roles of lecturers in realizing student independent learning is to provide facilities for learning media that can be accessed easily by students so that with the existence of learning media that support independent learning, students will be able to achieve learning goals. Additionally, based on the National Standards of Higher Education, each university is expected to be able to generate graduates who are devoted to God Almighty and are able to demonstrate religious attitudes, and always uphold human values in carrying out their duties based on religion, morals, and ethics, therefore it is not only emphasized to increase its potential and intelligence, but also consider religious values. Therefore, to achieve these goals there needs to be a synergy to integrate and link religion with science, in this case, the science of religion with accounting science, commonly referred to as the integration paradigm interconnect. This is reinforced by Rahayu's (2011) statement that, judging from the number of face-to-face meetings, courses in Islamic Religion are not sufficient with only two credits. Rahayu (2011) also add that various efforts were made to increase Islamic Religion Course class hours, but the answer that was often heard was that there had been so much burden on students' subjects that had to be completed, especially major courses, so there was no need to be given additional burdens of courses.

The integration-interconnection paradigm pioneered by Abdullah is an attempt to make a connection between religious science and general science incorporated in the natural sciences, social sciences, and humanities (Abdullah, et al., 2007: 53). It is expected that with the integration-interconnection paradigm learning that connects and links the verses of the Qur'an and Hadith with introductory accounting courses 1, students have more awareness that each knowledge comes from the Qur'an and Hadith, hence the accounting concepts obtained can be comprehensively understood and it can be applied in everyday life.

Based on the results of preliminary research through questionnaires to 30 accounting students of 2016 at the Faculty of Economics, State University of Malang who were randomly selected, a total of $90 \%$ of students who had filled out the questionnaire stated that there had been no insertion of religious values in the delivery of material in introductory courses 
accounting 1, both verbally when the lecturer explains in class, as well as from suggested learning support books. However, the student also realized that learning the science of religion was very important because basically, all sources of knowledge flowed to the Qur'an which would affect the behavior of daily life in terms of social interaction.

In addition, a total of $97 \%$ of students have used smartphones in their daily activities. Smartphones are used to search for additional knowledge through search engines (browsers), which are Google sites that are used more often by them. Meanwhile, in one smartphone students have many applications, in which social media features (Facebook, BlackBerry Messenger, WhatsApp, Line, Instagram) and entertainment (games) are the most widely used. As a result, smartphones that are supported by wifi facilities on campus are not optimally utilized in the learning process as expected. Therefore, if the smartphone can be used properly, it will also support the learning process of students. In addition, students will also be more pleased and comfortable since learning with the use of a smartphone will be more efficient and practical to be carried anywhere and can be used at any time. Based on this, the researchers took the initiative to develop a mobile learning media for accounting students at the State University of Malang in introductory accounting 1 courses based on integration-interconnection learning.

Previous research conducted by researchers, Ananda (2016) states that mobile learning media developed can attract the attention and interest of students, and in line with the concept of constructivism learning approach, which means that the media is able to direct students to the discovery of a concept that was born from the views and images and initiatives of students. Several other previous studies conducted by Saefi, et al (2015) state that mobile learning media has advantages in increasing mobility and saving time so as to enable students to access learning content in various places and times, provide learning opportunities at their own pace, and stimulate students to learn comfortably and attractively; and research conducted by Hanafi, et al (2012) states that the mobile learning system can be used as an economical but effective learning device that complements the student learning process.

The results of these studies indicate that there needs to be more attentive to the use of mobile applications or Android applications because it can facilitate students in accessing lessons. In addition, given the importance of inserting the foundations of a religious teaching to every lesson, it is important also when the mobile application development learning is integrated 
with integration-interconnection paradigm. In addition to providing new knowledge related to religious values, it will also encourage students' motivation to learn. This is in accordance with previous research conducted by Cahyani (2014). The results of the research stating that textbook compiled by inserting character value Quranic such a way can be used as a source of learning in the learning process so that students can gain new knowledge about the relationship between accounting, Al Qur'an and Hadith. Additionally, it can increase student motivation in studying accounting. Based on the description above, the researchers were intended to conduct this research.

\section{METHODS}

The development model used was the Borg \& Gall development model that has been modified into eight research steps, including (1) Initial research and data collection, (2) Planning, (3) Development of Product Drafts, (4) Expert Validation, (5) Revision of expert validation products, (6) Limited field trials by users, (7) Revision of trial results, (8) Completion of final products.

The trial design in the development of integration-interconnection-based m-learning media includes material expert trials, media expert trials, integration-interconnection expert trials, and respondents' trials, with each trial subject was an Accounting lecturer as material expert, Education Technology lecturer as a media expert, Sharia Accounting lecturer as an interconnection-integration expert, and a student of the Accounting Department of Malang State University as a respondent. Data collection instruments used in this development research were questionnaires. The level of instrument validity compiled by the researcher was considered through rational analysis, namely using the type of content validity. Data obtained from the results of filling out questionnaires of media experts, material experts, integrationinterconnection experts, and students for product feasibility tests were analyzed using percentage data techniques.

\section{RESULTS AND DISCUSSION}

\section{M-Learning Based on Integration-Interconnection Paradigm Interface}

The name of the Android application that is being developed by the researchers is

Merchandising Apps. The specification of its use is as an accounting learning media. The main 
menu contained in the integration-interconnection-based accounting learning application consists of four parts, namely material, quizzes, references, and product developer profiles. The material menu consists of four sub-menu sections which are elaborations of each of the topics, including an introduction to trading company accounting, recording stages, summarizing stages, and reporting stages. The essence of learning activities is in the material menu because in the application, there is a specific elaboration of the subject that is related to the sources in the Qur'an and Hadith.
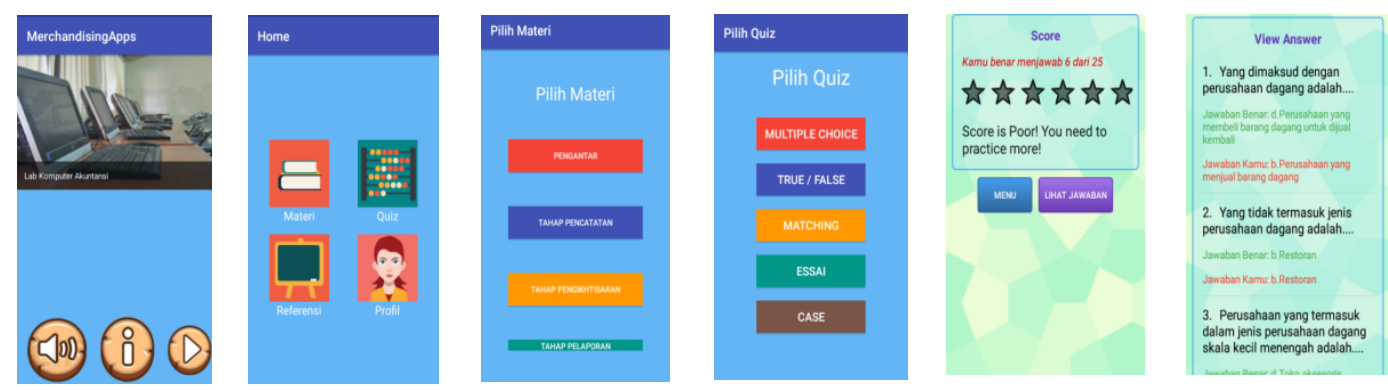

Figure 1. M-Learning Based on Integration-Interconnection Paradigm Interface in the form of Android Application

\section{Material Experts Validation}

The components contained in the expert questionnaire are (1) presentation of material, (2) interactivity, (3) items of questions, (4) feedback, and (5) others that are not included in the previous four rules. Data obtained from validation questionnaires by material experts are presented in the table as follows:

Table 1. Material Expert Validation Results

\begin{tabular}{|c|c|c|c|}
\hline \multirow{2}{*}{ Indicator } & & Percentage & Remarks \\
\hline & & $71 \%$ & Feasible \\
\hline & Presentation of Material & $67 \%$ & Feasible \\
\hline & Interactivity & $75 \%$ & Feasible \\
\hline & Items of questions & $75 \%$ & Feasible \\
\hline & Feedback Average & $75 \%$ & Feasible \\
\hline & Others & $73 \%$ & Feasible \\
\hline
\end{tabular}


Table 1 shows the results of the validation test of material experts obtaining eligibility criteria with a large percentage of material presentation eligibility $71 \%$, interactivity $67 \%, 75 \%$ items of questions, $75 \%$ feedback, and $75 \%$ other indicators. The total percentage of all items in the questionnaire for the material expert validation test is $73 \%$. Therefore, it can be concluded that the results of validation by material experts stated that the Android application based on an integration-interconnection paradigm for the subject of the accounting cycle of the trading company in the introductory course of accounting 1 is suitable to be utilized as a learning media.

Table 2. Comments and Suggestions of Material Experts Validation

\begin{tabular}{|c|l|}
\hline No & \multicolumn{1}{|c|}{ Comments and Suggestions } \\
\hline 1 & It is better to mention the competencies that will be achieved in the learning material \\
\hline 2 & $\begin{array}{l}\text { It is better to include a special or introductory presentation relating to the } \\
\text { interconnection-integration of each topic }\end{array}$ \\
\hline 3 & Questions for evaluation should be presented in each topic \\
\hline
\end{tabular}

Table 2 above presents the comment and suggestion for improvement from an expert validator for material improvements so that this application is more feasible to use.

\section{Media Expert Validation}

The components in the media expert validation questionnaire are as follows: (1) Technical Quality, (2) Presentation of material, (3) Interactivity, (4) items of questions, and (5) others that are not included in the previous four rules. Data obtained from validation questionnaires by media experts are presented in the following table.

Table 3. Media Expert Validation

\begin{tabular}{|c|c|c|c|}
\hline o & Indicator & Percentage & Remarks \\
\hline & Presentation of Material & $92 \%$ & Very \\
& & & Feasible \\
\hline & Interactivity & $100 \%$ & Very \\
& & & Feasible \\
\hline
\end{tabular}




\begin{tabular}{|c|c|c|c|}
\hline Items of questions & $100 \%$ & Very \\
& & & Feasible \\
\hline Feedback & $100 \%$ & Very \\
& & & Feasible \\
\hline Others & $100 \%$ & Fery \\
\hline & Average & $98 \%$ & Very \\
\hline & & & Feasible \\
\hline
\end{tabular}

Table 3 shows the results of the validation test of media experts obtaining very feasible eligibility criteria with a large percentage of the feasibility of technical quality $92 \%$, presentation of material $100 \%$, interactivity $100 \%, 100 \%$ items questions, and other indicators $100 \%$. The total percentage of all items in the media expert validation test questionnaire was $98 \%$. Therefore, it can be concluded that the results of validation by media experts stated that the Android application based on an integration-interconnection paradigm for the subject of the accounting cycle of the trading company in the introductory course of accounting 1 is very feasible to be utilized as a learning media

The comments and suggestions given by media experts were not many. Media experts argue that learning media is good enough and worthy of use without revision.

\section{Integration-Interconnection Expert Validation}

The components contained in the integration-interconnection validation questionnaire include (1) aspects of integration-interconnection and (2) Penetration of religious values. Data obtained from validation questionnaires by integration-interconnection experts are presented in the following table.

Table 4. Integration-Interconnection Expert Validation Results

\begin{tabular}{|l|r|r|r|}
\hline & Indicator & Percentage & Keterang \\
\hline o & & & an \\
\hline
\end{tabular}




\begin{tabular}{|c|c|c|c|}
\hline Aspects of integration- & $75 \%$ & Feasible \\
interconnection & & & \\
\hline & Topic presentation & $75 \%$ & Feasible \\
\hline Average & $75 \%$ & Feasible \\
\hline
\end{tabular}

Table 4 shows the results of the Integration-Interconnection Expert Validation and it obtained feasibility criterion with $75 \%$ for aspects of integration-interconnection and $75 \%$ topic presentation. The total percentage of all items in the questionnaire expert integrationinterconnection expert validation test is $75 \%$. Therefore, can be concluded that the results of the validation by the interconnection-integration expert states that that the Android application based on an integration-interconnection paradigm for the subject of the accounting cycle of the trading company in the introductory course of accounting 1 is very feasible to be utilized as a learning media

Table 5. Comments and Suggestions from Integration-Interconnection Expert Validation

\begin{tabular}{|c|l|}
\hline No & \multicolumn{1}{|c|}{ Comments and Suggestions } \\
\hline 1 & $\begin{array}{l}\text { A review of credit terms of payment, for example, } 2 / 10, \mathrm{n} / 30, \text { because there are } \\
\text { different opinions regarding this. }\end{array}$ \\
\hline 2 & We recommend that accounting information should not be taken from the blog. \\
\hline 3 & $\begin{array}{l}\text { In the overview phase and preparation of the financial statements, there is no basic } \\
\text { hadith. }\end{array}$ \\
\hline
\end{tabular}

Table 5 shows the suggestions and improvements from the validator-interconnection expert so that the products that are developed can be better and are very suitable for use and dissemination.

\section{Field Trial}

Quantitative data from field trials were obtained from the percentage of questionnaires filled in by respondents (students). This respondent consists of 100 students majoring in accounting who are randomly selected. The field trial validation questionnaire consists of five components, including (1) technical quality, (2) interactivity, (3) feedback, (4) items of questions, and (5) others that do not exist in all four previous indicators. Data obtained from limited group trials are presented in the following table. 
Table 6. The Results of Field Trial

\begin{tabular}{|c|c|c|c|}
\hline \multirow{2}{*}{ o } & Indicator & Percentage & Remarks \\
\hline & Presentation of Material & $77 \%$ & Feasible \\
\hline & Interactivity & $80 \%$ & Feasible \\
\hline & Items of questions & $77 \%$ & Feasible \\
\hline & Feedback & $81 \%$ & Very \\
& & & Feasible \\
\hline & Others & $81 \%$ & Very \\
& & & Feasible \\
\hline & Average & $79 \%$ & Feasible \\
\hline
\end{tabular}

Table 6 shows the results of the trial in the field which obtained feasibility criteria with a percentage of the feasibility of technical quality $77 \%$, material presentation $80 \%$, interactivity $77 \%$, items of questions $81 \%$, and other indicators $81 \%$. The total percentage of all questionnaire items by respondents was $79 \%$. Therefore, it can be concluded that based on user response, the android application based on an integration-interconnection paradigm for the subject of the accounting cycle of the trading company in the introductory course of accounting 1 is very feasible to be utilized as a learning media

Table 7. Comments and Suggestions from User Review

\begin{tabular}{|c|l|}
\hline No & \multicolumn{1}{|c|}{ Comments and Suggestions } \\
\hline 1 & The interface should be made more interesting \\
\hline 2 & The color domination should not be in blue \\
\hline 3 & Portrait layout of the application is better \\
\hline 4 & Items of questions should be varied \\
\hline
\end{tabular}

Based on table 7, it can be concluded that there are two suggestions for improvement and revision of the application, which makes the application look more attractive and adds a variety of other questions in the application. 


\section{Discussion}

According to the results of the study conducted by researchers during the field trials and validation by media expert validators, material experts, integration-interconnection expert, and respondents (students) regarding the android application based on integration-interconnection paradigm for subject of the accounting cycle of the trading company in the introductory course of accounting 1, it can be concluded that the application is suitable for use as a learning media. This indicates that the media developed by researchers can attract the attention and interest of students, and in line with the concept of constructivism learning approach, which means that the media is able to direct students to the discovery of a concept that is generated from the views and images and initiative of students.

The concept intended, which was generated from the perspective of students through this media is the concept of understanding, classification, stages of the trading company accounting cycle and the attitude that must be possessed and associated with the integration-interconnection paradigm. Students build this knowledge individually and internally through the learning material listed on the media. Then, related to the material presented, the researcher included the facts that occurred in the nearest period to be associated with the attitude that should be owned by students based on the foundation of the Qur'an and Hadith. Students construct this knowledge individually and internally through the material and facts described, which are then connected to the foundations in the Qur'an and Hadith. This is what is meant by cognitive constructivism, one of the two views of learning constructivism approaches.

Mobile learning media in the form of applications developed by researchers is in accordance with the concept of learning media revealed by Sadiman (2010), that applications can channel messages in the form of subject matter which includes the definition, format, and classification of accounting and the accounting cycle phase of trading companies through mobile computing tools. The application also sends messages to students about attitudes that must be possessed by accountants through Islamic studies that are linked to the foundation of the Qur'an and Hadith on each subject. Feasibility of the application has been tested and proved that the application can attract the attention and interest of students so that the mobile learning process can take place.

The research conducted regarding the development of integration-interconnection mobile learning media is in line with several previous studies, both in terms of product types and 
research results. The results of research conducted by Hanafi and Khairulanuar (2012) entitled Mobile Learning Environment System (MLES): The Case of Android-based Learning Application on Undergraduate's Learning, states that the mobile learning system can be used as an economical but effective learning media that complement student learning process. Meanwhile, mobile learning in the form of an android application in this study is also an economical but effective learning media.

Students do not need to spend a lot of money to obtain this media because for the long term the distribution of applications can be done through the Play store service. Thus, to obtain the application, students can simply download the application through the Play store service, then install the application on the smartphone they own. In fact, if students use an unpaid wifi network, it means that students can download the application for free.

The course regarding the trading company accounting cycle which is packaged in an android application is a new innovation in learning, which is adapted to the learning objectives and curriculum of introductory accounting learning 1 of the Faculty of Economics, State University of Malang, and adapted to current technological developments. Where recently, smartphone has become a daily device in the lives of the people, including students. With the learning innovation, students will not be bored with conventional learning in the classroom, because they can do learning through smartphones anywhere. This is in line with other studies conducted by Saefi, et al. (2015) stating that mobile learning media has advantages in increasing mobility and saving time so that students can access learning content in various places and times, providing learning opportunities at their own pace and stimulate learners to learn comfortably and attractively.

According to the trial and test on the learning application of the trading company accounting cycle empirically conducted in the field through validation by media expert validators, material, integration-interconnection, and respondents to determine the feasibility of the media, then two types of data namely quantitative data and qualitative data were obtained. Quantitative data in the form of a percentage in questionnaires were then confirmed in the eligibility criteria, while qualitative data in the form of comments and suggestions for improvement were obtained from the media expert validator, material, integrationinterconnection, and respondents. 
The validation results by the validator material expert stated that from the percentage of the total questionnaire score, the application developed by the researcher had a decent level of criteria. Learning materials on applications developed by researchers are declared feasible because they are in accordance with the competency standards that apply to introductory accounting courses 1 , especially the subject matter of the trading company accounting cycle. The material presented is considered to be shorter and easier to understand. In addition, this application is also considered to have more value because it includes the foundations of the Qur'an and Hadith in accordance with the learning material.

However, the material expert validator gave several suggestions for improvement, including: first, listing the competencies to be achieved in learning; second, giving a special explanation regarding the integration-interconnection paradigm that will be displayed in the learning material; and thirdly, the evaluation or items of questions in the application should be made for each subsubject. Hence, even though the media is already in the proper criteria, the conclusion of the material validator is that the integration-interconnection-based mobile learning media is appropriate for use with revisions according to suggestions.

The results of the product revision based on the advice of the expert material validator, the first suggestion is to include the competencies to be achieved and the third suggestion is to increase the practice of questions in each sub-subject in the product developed which are not included in the learning, this is because the application is only an informative application. The intended information here is in accordance with one of the interconnection-integration models, where the use of applications is only limited to providing additional knowledge related to the integration-interconnection paradigm in the trading company accounting cycle. Therefore, this application is made not to be the main source used in the learning process, but only as a complementary media to learning.

The results of validation by media expert validators obtained a higher percentage of questionnaire scores compared to the validation of material experts. All indicators of the media expert validation questionnaire statement have very reasonable criteria levels. This mobile learning application is declared very feasible because in general, this application is interesting, both in terms of appearance and content. Based on the assessment of media validation experts, integration-interconnection-based mobile learning applications for trading company accounting cycle in the introductory accounting 1 course is very feasible to use and without the need for media revisions. 
To strengthen the aggravating of the material associated with the Qur'an and Hadith, the researchers also included validators of integration-interconnection experts as a complement to the products developed. In the validation of the integration-interconnection expert, the validator assessed that the feasibility level of the developed application was included in the feasible category. However, there are some suggestions and comments to improve the application, such as the first, there needs to be a review of the terms of credit repayment, because there are differences of opinion about this matter; second, it is recommended that accounting information should not be taken from a free blog; and thirdly, in the summary phase and the preparation of the financial statements, it is necessary to add the basis of hadith. The integrationinterconnection expert validation concluded that mobile learning media based on integrationinterconnection for the trading company accounting cycle in the introductory accounting 1 course is feasible with revision.

The results of the product revision based on the advice of the validator of the integrationinterconnection expert are the first suggestion relating to the terms of credit repayment and the third relating to the addition of relevant verses and hadiths has been revised as suggested. But for the second suggestion related to the source of accounting information, the researcher did not revise it. This is because accounting information is no longer included in the application because accounting information is not very important and influences learning the material.

In addition to the validator of expert media, material, and interconnection-integration experts, product feasibility tests were also conducted by respondents of 100 students. These respondents were randomly selected from students of the accounting department batch 2016 . The results of the validation by the respondents indicated that the application is feasible to be used, with some comments and suggestions for improvement. The improvement suggestions given by respondents are more focused on the appearance of the learning media, which is then improved and revised by the researcher.

In general, the learning media in the form of integration-interconnection based mobile learning applications for the accounting cycle of trading companies in the introduction to accounting 1 is feasible. The application is considered feasible because in general, they have attracted the attention of students. In addition to its attractive appearance, the application is also practically used and easy to carry everywhere. In addition, the learning material presented in the 
application is also simple and easy to understand. Moreover, the foundations of the Qur'an and Hadith are in accordance with the material.

However, research conducted by researchers is certainly inseparable from the advantages and disadvantages or limitations. The advantages of this product research and development are as follows: first, the application developed supports students to utilize and maximize smartphones in the learning process, because it can be obtained for free, practical, and can be used anywhere and anytime as a media of independent learning by students; second, this application uses the integration-interconnection paradigm that connects learning material with the foundations of the Qur'an and Hadith, which provides information relating to attitudes that must be possessed in the social interaction.

This developed application is also not free from limitations. As for the limitations of the results of the development of m-learning applications based on integration-interconnection, among others: first, the indicators used to measure interconnection-integration are still not valid, there are no sources or references, it still cannot be said as an indicator, because it is still very general and not Specific; second, this application can only be applied to smartphones with an Android operating system; thirdly, the application cannot display the problem exercises with long answers.

\section{CONCLUSION}

Based on the results of the study in general, it can be concluded that learning media in the form of m-learning applications based on integration-interconnection for the accounting cycle of trading companies is very feasible to use. In order for the use of the application to run properly and truly support the learning of students, then the advice on the use of products needs to be considered. Some suggestions that need to be considered are the material contained in it that needs to be considered carefully so that it can enhance the students' knowledge that Islam is a human life guide that does not merely regulate the relationship between humans and God, but also regulates relations among human beings. It is necessary to disseminate applications through Playstore in android in order to make the application developed being known widely. Thus the development of this media is not limited to accounting students at the State University of Malang. 


\section{REFERENCES}

Abdullah. 2007. Islamic Studies: Dalam Paradigma Integrasi-Interkoneksi (Sebuah Antologi). Yogyakarta: Suka Press.

Akbar, S.. 2013. Instrumen Perangkat Pembelajaran. Bandung: PT. Remaja Rosdakarya.

Ananda, M. R., dkk. 2016. Pengembangan Media Mobile Learning Berbasis Scientific Approach Mata Pelajaran Akuntansi dan Keuangan untuk Sekolah Menengah Kejuruan (SMK), hlm.284, dalam Prosiding NSAFE.

Arief, S., Sadiman, dkk. 2010. Media Pendidikan. Jakarta: Raja Grapindo Persada.

Arsyad, A.. 2004. Media Pembelajaran. Jakarta: PT. Raja Grafindo Persada.

Arsyad, A.. 2011. Media Pembelajaran. Jakarta: Rajawali Pers.

Cahyani, F. D.. 2014. Pengembangan Buku Ajar Akuntansi Berbasis Integrasi-Interkoneksi untuk Kelas XI IPS di MAN 3 Malang, (Online), (http://karyailmiah.um.ac.id/index.php/akutansi/article/view/33142), diakses pada 22 Desember 2016.

Darmawan, D.. 2012. Inovasi Pendidikan. Bandung: PT. Remaja Rosdakarya.

Hanafi, H. F. \& Khairulanwar, S.. 2012. Mobile Learning Environment System (MLES): The Case of Android-based Learning Application on Undergraduates Learning. International Journal of Advanced Computer Science and Application, 3(3): hlm. 5, (Online), dalam IJACSA (http://arxiv.org/ftp/arxiv/papers/1204/1204.1839), diakses 22 Oktober 2016.

Hanafiah, N. \& Cucu, S. 2012. Konsep Strategi Pembelajaran. Bandung: Refika Aditama.

Harahap. 2014. Akuntansi Islam. Jakarta: Bumi Aksara, (Online), (http://digilib.uinsuka.ac.id/7207/1/BAB\%201\%2C\%20V\%2C\%20DAFTAR\%20PUSTA KA.pdf), diakses pada 22 Januari 2017.

Hitipiew, I. 2009. Belajar dan Pembelajaran. Malang: Fakultas Ilmu Pendidikan Universitas Negeri Malang.

Kuntowijoyo. 2005. Islam Sebagai Ilmu, Cet. Ke-2. Jakarta: Penerbit Teraju.

Nurgiyantoro, B., Gunawan, \& Marzuki. 2012. Statistik Terapan untuk Penelitian Ilmu-Ilmu Sosial. Yogyakarta: Gadjah Mada University Press.

Nursyahidah, F. 2012. Research \& Development V3 Development Research, (Online), (http://digilib.uin-suka.ac.id/2012/06/research-and-development-vs-developmentresearch), diakses 26 Januari 2017.

Rahayu, S. 2011. Pendidikan Agama Islam Pada Perguruan Tinggi Umum (Kedudukan, Problem dan Prospeknya), (Online), (http:// digilib.uin-suka.ac.id/2011/07/pendidikanagama-islam-pada-perguruan.html?m=1), diakses pada 15 Juli 2017.

Safa'atun. 2013. Pengembangan Modul IPA Fisika Berbasis Integrasi-Interkoneksi untuk Siswa SMP/MTs. Skripsi, (Online), (http://digilib.uinsuka.ac.id/7315/1/BAB\%20I\%2C\%20V\%2C\%20DAFTAR\%20PUSTAKA.pdf), diakses pada 25 Januari 2017.

Saputri, I. J.. 2015. Pengembangan Media Prezi untuk Meningkatkan Motivasi Belajar Siswa, (Online), (http://karya-ilmiah.um.ac.id/index.php/akutansi/ article/view/44132), diakses pada 5 Mei 2017.

Sari, R. A. 2012. Teori Konstruktivistik (Konstruktivisme) dan Aplikasinya, (Online),(http://riaarusmsari.blogspot.co.id/2012/06/teori-konstruktivistikkonstruktivisme.html), diakses 25 Januari 2017.

Sugiyono. 2008. Metode Penelitian Kuantitatif Kualitatif dan R\&D. Bandung: Alfabeta.

Sukmadinata, N. S. 2012. Metode Penelitian Pendidikan. Bandung: Remaja Rosdakarya.

Suparti. 2016. Metode Penelitian Pengembangan Inovasi Pembelajaran. Malang: UM Press. 
Suprayogo, Imam. 2009. Tarbiyah Uli al-Albab;Dzikr, fikr, dan Amal shaleh. Malang: UIN Malang Press.

Universitas Negeri Malang. 2010. Pedoman Penulisan Karya Ilmiah Edisi Kelima. Malang: Universitas Negeri Malang.

Wirawan, P. W. 2011. Pengembangan Kemampuan E-Learning Berbasis Wib ke dalam MLearning. Jurnal Universitas Diponegoro. 2(4): hlm.22-23, (Online), (http://ejournal. undip.ac.id/index.php/jmasif/article/view/2655), diakses pada 26 Januari 2017. 